\title{
Hypolipidemic effect of triphala (Terminalia chebula, Terminalia belerica and Emblica officinalis) on female albino rats.
}

\author{
Fatma Ahmed Eid , Eman G.E. Helal and Amira M. Salah EL-Din Ahmed El- \\ Wahsh \\ Zoology Department, Faculty of Science, Al-Azhar University
}

\begin{abstract}
Hyperlipidemia, hyperlipoproteinemia or dyslipidemia is the presence of elevated or abnormal levels of lipids and / or lipoproteins in the blood. Lipid and lipoprotein abnormalities are extremely common in the general population and are regarded as a highly modifiable risk factor for cardiovascular disease due to the influence of cholesterol, one of the most clinically relevant lipid substances in atheroscterosis.
\end{abstract}

\section{Aim of the work:}

This study aimed to evaluate the possible treatment and protective effect of triphala on hyperlipidemic rats.

\section{Material and methods:}

Six groups (5rat/group) of female albino rats (Rattus albinus) were used. The 1st group used as control, in the $2^{\text {nd }}$ group hyperlipidemia ( $25 \%$ fat $\& 2 \%$ cholesterol) was induced for 3 weeks only then sacrified, the $3^{\text {rd }}$ group was hyperlipidemic rats for 3 weeks then left for other 3 weeks without any additional treatment as a recovery period, the $4^{\text {th }}$ group served as hyperlipidemic group for 3 weeks then treated with triphala for another 3 weeks $(25 \mathrm{mg} / 100 \mathrm{gm}$ b. wt.), the $5^{\text {th }}$ group was hyperlipidemic ( $25 \%$ fat $\& 2 \%$ cholesterol) for 6 weeks and the $6^{\text {th }}$ group served as hyperlipidemic rats for 6 weeks, and at the same time given triphala $(25 \mathrm{mg} / 100$ gm b. wt.) by oral administration.

\section{Results:}

The biochemical parameters showed highly significant increase in the body weight, serum glucose, ASAT, ALAT, GGT, LDH, total protein, albumin and total lipids in liver .Many histopathological and histochemical changes were detected in liver tissue of the hyperlipidemic rats. Meanwhile, the treatment with triphala ameliorated the biochemical parameters, histological and histochemical results.

\section{Conclusion:}

It is recommended to use triphala in diets for hyperlipidemic patients or those people who have hyperlipidemic family history.

\section{Keywords:}

Hyperlipidemia, Triphala, Lipid profile, Albino rats, Physiological parameters, Histopathological and histochemical changes.

\section{Introduction}

Hyperlipidemia is a heterogeneous disorder involving multiple etiologies. It is commonly characterized by an increased flux of free fatty acids (FFA), raised triglycerides, low-density lipoprotein
(LDL)-cholesterol and apolipoprotein B (apo B) levels, and reduced plasma highdensity lipoprotein (HDL)-cholesterol concentration, as a consequence of metabolic effects, or dietary and lifestyle habits (Kolovou et al., 2005; Feng et al., 2011). 
The use of medicinal plants for health started from thousands of years and still a part of the medical practice in China, Egypt, India, and other developing countries. Modern pharmaceuticals still contain at least $25 \%$ of drugs derived from the plants (Thomas, 2000).

Herbal medicines are highly in demand in developed as well as developing countries for primary health care because of their wide biological and medicinal activities, higher safety margins, and lower costs (Palav and D'mello, 2006; Chattopadhyay and Bhattacharyya, 2007).

The hyperlipidemia-lowering effect of different plants has been well studied and various plants were shown to be helpful in lowering plasma lipid levels and encouraging safety profile. Many plants therefore are considered to be useful means to prevent disorders such as atherosclerosis (Choudhary et al., 2005).

One of the most important plants used as hyperlipidemia-lowering factor in the folk medicine in Egypt is triphala herb. Triphala, meaning "three fruits", is made from fruits of three trees that grow throughout India and the Middle East, including amalaki fruit (Emblica officinalis), bibhitaki fruit (Terminalia belerica), and haritaki fruit (Terminalia chebula).

According to Jagetia et al. (2004) triphala is used to promote appetite and digestion, increase the number of red blood cells and aid in removal of undesirable fat in the body, when dissolved in the mouth, Triphala is used to clear congestion and headaches. Other claimed benefits include helping to maintain normal blood sugar levels, as well as improvement in skin tone and colour. Triphala prevents aging, imparts immunity and improves mental faculties. It also helps to detoxify the liver and purify blood.

Sandhya et al. (2006) reported that triphala, an ancient herbal blend, is one of the most commonly used herbal remedies in the ayurvedic system of healing. Ayurvedic medicine originated in ancient India, has developed over thousands of years, and is one of the oldest systems of healing. Thus triphala is one of the longest-used herbal remedies in the world.

Triphala is prescribed as the first line treatment of many aliments as Laxative, detoxifying agent and rejuvenator in Ayurveda. Its antidiabetic, antimutagenic, purgative and radio protective activities has been reported (Jagetia et al., 2002; Kaur $\boldsymbol{e t}$ al., 2002; Sabu and Kuttan, 2002; Arora et al., 2003).

\section{Material and methods}

\section{1-Experimental animals:}

The present work was carried out on thirty mature female albino rats $(150 \pm 20 \mathrm{~g})$. They were obtained from the Nile Company for Pharmaceutical and Chemical Industries. The experimental animals were randomly divided into six groups (5/group) and fed on rodent diet. The rats stayed for 3 weeks to adapt the place then the experimental steps were started.

\section{2-Experimental design:}

Six groups were used in this study each containing 5 female albino rats.

1- The $1^{\text {st }}$ group: served as control (C).

2 - The $2^{\text {nd }}$ group: hyperlipidemic rats $(25 \%$ fat \& $2 \%$ cholesterol) 3 weeks only then they were sacrificed (H3).

3 - The $3^{\text {rd }}$ group: served as hyperlipidemic rats for 3 weeks then left other

3 weeks without any additional treatment as a recovery period $(\mathrm{R})$.

4- The $4^{\text {th }}$ group: served as hyperlipidemic rats for 3 weeks then treated

with triphala for 3 weeks $(25 \mathrm{mg} / 100 \mathrm{gm}$

b. wt.) (H3T).

5- The $5^{\text {th }}$ group: included hyperlipidemic rats ( $25 \%$ fat $\& 2 \%$ cholesterol)

for 6 weeks (H6).

6- The $6^{\text {th }}$ group: served as hyperlipidemic rats for 6 weeks, and at the

same time they were given triphala (25 $\mathrm{mg} / 100 \mathrm{gm}$ b. wt.) by oral

administration(H6T).

Each rat was weighted at the beginning and the end of the experiment and percentage of body weight changes were calculated. 



\section{Preparation for measure total lipids in liver:}

$0.1 \mathrm{gm}$ of liver was placed in $1 \mathrm{ml}$ of $\mathrm{KOH}$ $(30 \%)$ and left to be digested in the incubator at $37^{\circ} \mathrm{C}$.

\section{Collection of rat's serum:}

At the end of the experiment, animals were decapitated and blood samples were collected from the retro-orbital plexus. The samples were collected in clean dry graduated centrifuge tubes and left for 20 minutes to clot, then centrifuged at 5000 rpm, for 15 minutes. Serum was separated and kept at $-20^{\circ} \mathrm{C}$ until analysis.

Serum glucose was estimated according to Trinder (1984). Aspartate aminotransferase (ASAT) was performed according to Bergmeyer (1978). Alanine aminotransferase (ALAT) was determined according to Breuer (1996). $\gamma$ Glutamyltransferase $(\gamma-\mathrm{GT})$ was done according to Szasz and Persijn (1974). Serum LDH (Lactate dehydrogenase) concentration was done according to the kinetic ultraviolet method of Young (1990). Serum total protein was performed by the method of Tietz (1994). Serum albumin was done by the method of Doumas et al. (1971). Total lipids in liver was done by the method of Kaplan (1984).

\section{The histological and histochemical preparation:}

Fresh specimens of liver were taken from the control and experimental groups. The specimens were fixed in $10 \%$ neutral buffered formol and Carnoy's fluid for the histological and histochemical studies. Sections were then cut at $5 \mu$ thickness and stained by haematoxylin and eosin stain according to the method of Drury \& Wallington (1980), by periodic acid Schiff technique for demonstrating glycogen (Pearse,1977), by mercuric bromophenol blue method for detecting total protein (Mazia et al., 1953), and by Mallory's trichrome stain for demonstrating collagen fibers (Pearse, 1977).

\section{Statistical analysis:}

The data are expressed as means \pm standard errors (SE). The (T) test was used to elucidate the differences between treated and control groups (Snedecor and Cochran, 1980). A difference was considered significant at $\mathrm{p}<0.05$ or $\mathrm{p}<$ 0.01 .

\section{Results}

The percentage of body weight gain significantly increased $(\mathrm{P}<0.01)$ in all treated groups. Concerning serum glucose level, the present data showed severe hyperglycemia $(\mathrm{P}<0.01)$ in all treated groups. (Table 1). Results of the present study showed a highly significant increase $(\mathrm{P}<0.01)$ in ASAT, ALAT, GGT and LDH activities in the treated groups when compared with control rats (Table 2).

Also, highly significant increase $(\mathrm{P}<0.01)$ was observed in serum total protein and albumin concentrations in all treated groups when compared with the control one during the experimental period (Table 3). Globulin concentration showed insignificant change in all treated groups (Table 3). All treated groups also showed insignificant change in albumin/globulin ratio (A/G ratio) except in the group that was fed hyperlipidemic diet for 6 weeks where it showed highly significant increase $(\mathrm{P}<0.01)$, and also in the group that was treated with triphala for 6 weeks, where it showed a significant increase $(\mathrm{P}<0.05)$ as compared with the control animals (Table 3).

Concerning liver total lipids highly significant increase $(\mathrm{P}<0.01)$ was recorded in all treated groups except in the group that was fed hyperlipidemic diet for 3 weeks then was treated with triphala for another 3 weeks where it showed highly significant decrease $(\mathrm{P}<0.01)$ when compared with the control group (Table 4).

Hyperlipidemia for 6 weeks elevated all the biochemical parameters, while feeding triphala for 3 weeks after stopping fat diets recorded the lowest measures of these parameters .

Figs. (1\&2) show normal histological pattern of liver tissue of a control rat. Hyperlipidemic rats of groups H3 showed 
many dystrophic changes in the liver tissue .These changes included: highly distorted and ruptured endothelial lining of the blood vessels, increased lymphocytic infiltration in the portal area, haemolysed RBCs inside the blood vessels, degenerated and vacuolated hepatocytes (fig. 3). A slight amelioration was noticed in liver tissue of rats of the recovery group (fig. 4). Nearly normal hepatocytes were observed in liver tissue of rats of group H3T. Well developed cords of hepatocytes surrounded the central vein and the portal area appeared well developed (fig. 5). Mild recovery was noticed in liver tissue

of rats of group H6T (fig. 6).

Normal distribution of collagen fibers was observed in figs.(7\&8). Increased collagen fibers were observed in liver tissue of groups $\mathrm{H} 3$ or $\mathrm{H} 6$, the recovery group and those treated with fats and triphala for 3 or 6 weeks ( figs. 9,10,11 and 12).

Normal distribution of total proteins in the hepatic tissue of a control rat was observed in figs.(13\&14). Highly reduced total proteins was observed in liver tissue of group $\mathrm{H} 3$ (fig. 15), but the $\mathrm{R}$ group showed a mild decrease (fig. 16). Meanwhile, nearly normal total proteins were observed in hepatocytes of liver tissue of groups H3T or H6T (figs.17 \& 18).

Concerning all the previous biochemical parameters, histological and histopathological changes it was found that using triphala was better than relying only excluding dietary fats after hyperlipidemic diets without any additional treatment (recovery groups).

Table (1): Percentage of body weight change and Serum glucose level ( $\mathrm{mg} / \mathrm{dl})$ in female albino rats after induction of hyperlipidemia and treating with triphala.

\begin{tabular}{|c|c|c|c|c|c|c|c|}
\hline \multirow{2}{*}{\multicolumn{2}{|c|}{ Group }} & \multirow{3}{*}{$\begin{array}{l}\text { Cont } \\
\text {-rol } \\
5.50\end{array}$} & \multicolumn{3}{|c|}{3 weeks } & \multicolumn{2}{|c|}{6 weeks } \\
\hline & & & \multirow{2}{*}{12.92} & \multirow{2}{*}{ 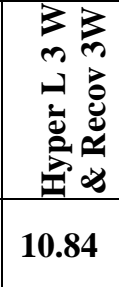 } & \multirow{2}{*}{ 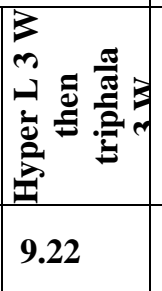 } & \multirow{2}{*}{ 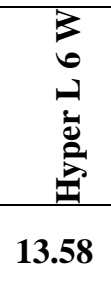 } & \multirow{2}{*}{ 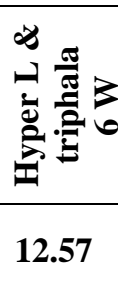 } \\
\hline $\begin{array}{l}\text { Body } \\
\text { weigh }\end{array}$ & $\begin{array}{l}\text { Mea } \\
\text { n }\end{array}$ & & & & & & \\
\hline \multirow{2}{*}{$\begin{array}{r}-t \\
\text { chang } \\
\text { e }(\%)\end{array}$} & $\pm \mathrm{SE}$ & 0.65 & 12 & 0.98 & 1.39 & 0.70 & 1.62 \\
\hline & $\mathbf{P}$ & -- & 0.01 & $<0.01$ & $<0.01$ & $<0.01$ & $<0.01$ \\
\hline \multicolumn{2}{|c|}{$\%$ of change } & -- & 134.9 & 97.0 & 67.6 & 146.9 & 128.5 \\
\hline \multirow{3}{*}{$\begin{array}{l}\text { Gluo } \\
-\mathrm{s} \\
\text { (mg/ } \\
\text { dl) }\end{array}$} & $\begin{array}{l}\text { Mea } \\
\text { n }\end{array}$ & 64.8 & 99.0 & 76.2 & 74.4 & 122.6 & 87.4 \\
\hline & $\pm \mathrm{SE}$ & 1.7 & 2.4 & 1.7 & & 1.03 & 1.03 \\
\hline & $\mathbf{P}$ & & $<0.01$ & $<0.01$ & $<0.01$ & $<0.01$ & $<0.01$ \\
\hline \multicolumn{2}{|c|}{$\%$ of change } & -- & 52.7 & 17.59 & 14.81 & 89.19 & 34.8 \\
\hline
\end{tabular}

$\begin{array}{lc}\text { Hyper } L=\text { Hyperlipidemia } & \begin{array}{c}\text { Recov }=\text { recovery } \\ \text { N.s }=\text { non significant }\end{array}\end{array} \quad 3 \mathrm{~W}=3$ weeks


Table (2): Aspartate aminotransferase (ASAT), Alanine aminotransferase (ALAT) gamma glutamyl transferase (GGT) and Lactate dehydrogenase $(L D H)$ activities in female albino rats after induction of hyperlipidemia and treating with triphala.

\begin{tabular}{|c|c|c|c|c|c|c|c|}
\hline \multirow{2}{*}{\multicolumn{2}{|c|}{ Group }} & \multirow{3}{*}{$\begin{array}{l}\text { Contr- } \\
\text { ol }\end{array}$} & \multicolumn{3}{|c|}{3 weeks } & \multicolumn{2}{|c|}{6 weeks } \\
\hline & & & \multirow{2}{*}{89.8} & \multirow{2}{*}{ 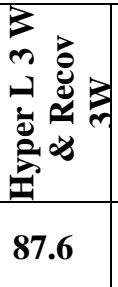 } & \multirow{2}{*}{ 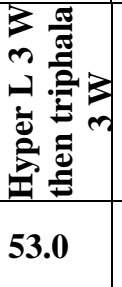 } & \multirow{2}{*}{ 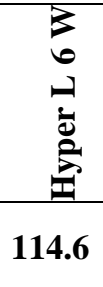 } & \multirow{2}{*}{ 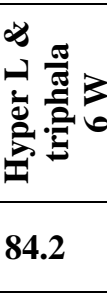 } \\
\hline \multirow[t]{3}{*}{$\begin{array}{r}\text { ASAT } \\
(\mathbf{U} / \mathbf{L})\end{array}$} & $\begin{array}{l}\text { Mea } \\
\text { n }\end{array}$ & & & & & & \\
\hline & $\pm \mathrm{SE}$ & & & 2.99 & 1.96 & & 0.96 \\
\hline & $\mathbf{P}$ & & & 0.01 & $<0.01$ & & 0.01 \\
\hline \multicolumn{2}{|c|}{$\%$ of change } & - & 176.3 & 169.5 & 63.0 & 252.6 & 159.0 \\
\hline \multirow[t]{3}{*}{$\begin{array}{l}\text { ALAT } \\
\text { (U/L) }\end{array}$} & $\begin{array}{l}\text { Mea } \\
\text { n }\end{array}$ & 23.2 & 73.4 & 53.0 & 32.4 & 107.8 & 44.4 \\
\hline & $\pm \mathrm{SE}$ & & & .1 & 1.6 & & 1.8 \\
\hline & $\mathbf{P}$ & & & $<0.01$ & $<0.01$ & $\mathbf{6 . 0 1}$ & $<0.01$ \\
\hline \multicolumn{2}{|c|}{$\%$ of change } & - & 216.3 & 128.4 & 39.6 & 364.6 & 91.3 \\
\hline \multirow[t]{3}{*}{$\begin{array}{r}\text { GGT } \\
(\mathbf{U} / \mathbf{L})\end{array}$} & $\begin{array}{l}\text { Mea } \\
\text { n }\end{array}$ & 20.2 & 40.8 & 39.6 & 34.0 & 45.4 & 42.6 \\
\hline & $\pm \mathbf{S E}$ & & & 0.57 & 0.625 & 35 & 0.75 \\
\hline & $\mathbf{P}$ & 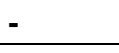 & & $<0.01$ & $<0.01$ & $<0.01$ & $<0.01$ \\
\hline \multicolumn{2}{|c|}{$\%$ of change } & - & 55.7 & 51.1 & 29.7 & 73.2 & 62.5 \\
\hline \multirow[t]{3}{*}{$\begin{array}{l}\text { LDH } \\
\text { (U/L) }\end{array}$} & $\begin{array}{l}\text { Mea } \\
\text { n }\end{array}$ & 177.8 & 363.0 & 244.0 & 193.0 & 391.6 & 276.6 \\
\hline & $\pm \mathbf{S E}$ & & & 2.26 & 2.3 & 4.3 & 9.4 \\
\hline & $\mathbf{P}$ & 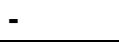 & 0.01 & $<0.01$ & $<0.01$ & $<0.01$ & $<0.01$ \\
\hline \multicolumn{2}{|c|}{$\%$ of change } & - & 104.1 & 37.2 & 8.5 & 120.2 & 55.5 \\
\hline
\end{tabular}

Hyper L = Hyperlipidemia 6W $=6$ Weeks
Recov $=$ recovery N.s = non significant
$3 \mathrm{~W}=3$ weeks 
Table (3): Total protein, Albumin, Globulin concentrations and Albumin/Globulin ratio $(A / G)$ ratio in female albino rats after induction of hyperlipidemia and treating with triphala .

\begin{tabular}{|c|c|c|c|c|c|c|c|}
\hline \multirow{2}{*}{\multicolumn{2}{|c|}{ Proup }} & \multirow{3}{*}{$\begin{array}{l}\text { Contr- } \\
\text { ol }\end{array}$} & \multicolumn{3}{|c|}{3 weeks } & \multicolumn{2}{|c|}{6 weeks } \\
\hline & & & \multirow{2}{*}{8.46} & \multirow{2}{*}{ 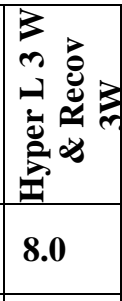 } & \multirow{2}{*}{ 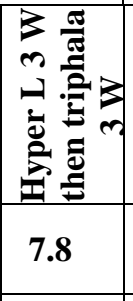 } & \multirow{2}{*}{ 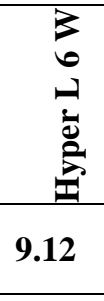 } & \multirow{2}{*}{ 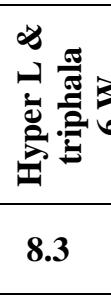 } \\
\hline $\begin{array}{r}\text { Total } \\
\text { protei }\end{array}$ & $\begin{array}{l}\text { Mea } \\
\text { n }\end{array}$ & & & & & & \\
\hline \multirow{2}{*}{$\begin{array}{r}-n \\
(g / d l)\end{array}$} & $\pm \mathrm{SE}$ & 0.127 & 0.17 & 0.145 & 0.114 & 0.065 & $\mathbf{0 . 0 5 7}$ \\
\hline & $\mathbf{P}$ & & $<0.01$ & $<0.01$ & $<0.01$ & $<0.01$ & $<0.01$ \\
\hline \multicolumn{2}{|c|}{$\%$ of change } & & 26.2 & 19.4 & 16.4 & 36.1 & 23.8 \\
\hline \multirow{3}{*}{$\begin{array}{r}\text { Albu- } \\
\text { min } \\
(\mathrm{g} / \mathrm{dl})\end{array}$} & $\begin{array}{l}\text { Mea } \\
\text { n }\end{array}$ & 4.32 & 5.7 & 5.4 & 5.1 & 6.5 & 5.8 \\
\hline & $\pm \mathrm{SE}$ & 0.143 & 0.065 & 0.103 & 0.108 & 0.096 & 0.074 \\
\hline & $\mathbf{P}$ & 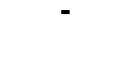 & $<0.01$ & $<0.01$ & $<0.01$ & $<0.01$ & $<0.01$ \\
\hline \multicolumn{2}{|c|}{$\%$ of change } & - & 31.9 & 25.0 & 18.0 & 50.4 & 34.2 \\
\hline \multirow{3}{*}{$\begin{array}{r}\text { Globu } \\
\text {-lin } \\
(\mathrm{g} / \mathrm{dl})\end{array}$} & $\begin{array}{l}\text { Mea } \\
\text { n } \\
\end{array}$ & 2.38 & 2.74 & 2.56 & 2.7 & 2.6 & 2.52 \\
\hline & $\pm \mathrm{SE}$ & 0.163 & 0.160 & 0.216 & 0.086 & 0.061 & 0.119 \\
\hline & $\mathbf{P}$ & & N.S & N.S & N.S & N.S & N.S \\
\hline \multicolumn{2}{|c|}{$\%$ of change } & & 15.1 & 7.5 & 13.4 & 9.2 & 5.88 \\
\hline \multirow[t]{3}{*}{$\begin{array}{c}\mathbf{A} / \mathbf{G} \\
\text { ratio }\end{array}$} & $\begin{array}{l}\text { Mea } \\
\text { n }\end{array}$ & 1.85 & 2.106 & 2.182 & 1.896 & 2.512 & 2.324 \\
\hline & $\pm \mathbf{S E}$ & 0.177 & 0.128 & 0.249 & 0.089 & 0.094 & 0.128 \\
\hline & $\mathbf{P}$ & & N.S & N.S & N.S & $<0.01$ & $<0.05$ \\
\hline \multicolumn{2}{|c|}{$\%$ of change } & & 13.8 & 17.9 & 2.4 & 35.7 & 25.6 \\
\hline
\end{tabular}

Hyper L = Hyperlipidemia $6 \mathrm{~W}=6$ Weeks
Recov $=$ recovery $\quad 3 \mathrm{~W}=3$ weeks N.s = non significant 
Hypolipidemic effect.....

Table (4): The level of liver total lipids in female albino rats after induction of hyperlipidemia and treating with triphala.

\begin{tabular}{|c|c|c|c|c|c|c|c|}
\hline & \multirow{3}{*}{$\begin{array}{l}\begin{array}{l}\text { Contr } \\
\text { ol }\end{array} \\
4.52\end{array}$} & \multicolumn{3}{|c|}{3 weeks } & \multicolumn{2}{|c|}{6 weeks } \\
\hline & & & \multirow{2}{*}{ 5.64 } & \multirow{2}{*}{ 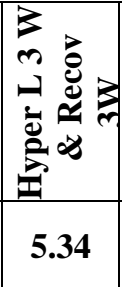 } & \multirow{2}{*}{ 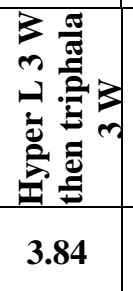 } & \multirow{2}{*}{ 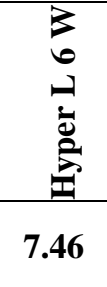 } & \multirow{2}{*}{ 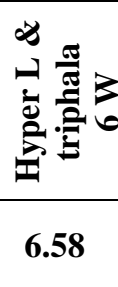 } \\
\hline \multirow{3}{*}{$\begin{array}{r}\text { Liver } \\
\text { total } \\
\text { lipids } \\
(\mathrm{g} / \mathrm{l})\end{array}$} & $\begin{array}{l}\text { Mea } \\
\text { n }\end{array}$ & & & & & & \\
\hline & $\pm \mathrm{SE}$ & 0.21 & 0.13 & 0.125 & 0.044 & 0.16 & 0.065 \\
\hline & $\mathbf{P}$ & - & $<0.01$ & $<0.01$ & $<0.01$ & $<0.01$ & $<0.01$ \\
\hline \multicolumn{2}{|c|}{$\%$ of change } & - & 24.7 & 18.1 & 15.04 & 65.04 & 45.5 \\
\hline
\end{tabular}
Hyper $\mathrm{L}=$ Hyperlipidemia
Recov $=$ recovery
$3 \mathbf{W}=3$ weeks
$6 \mathrm{~W}=6 \mathrm{Weeks}$
N.s = non significant 
Fatma Eid... et al
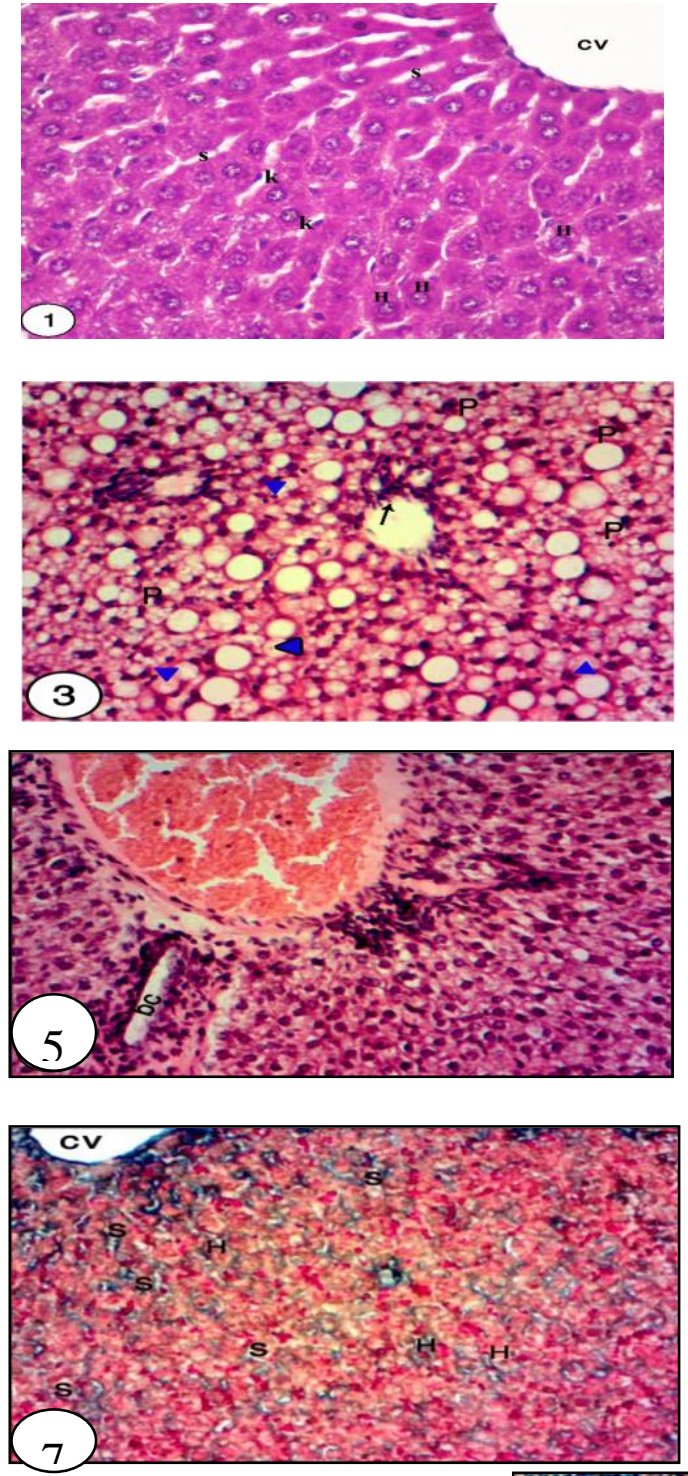
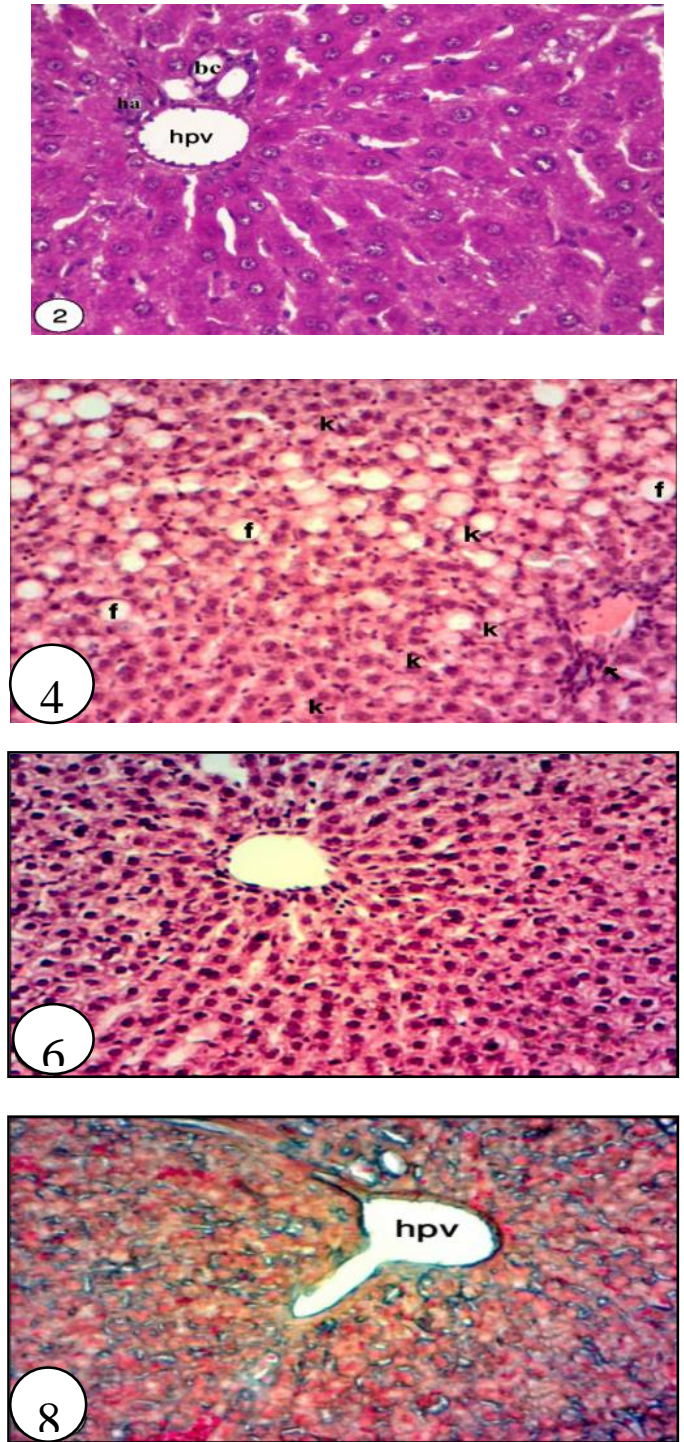

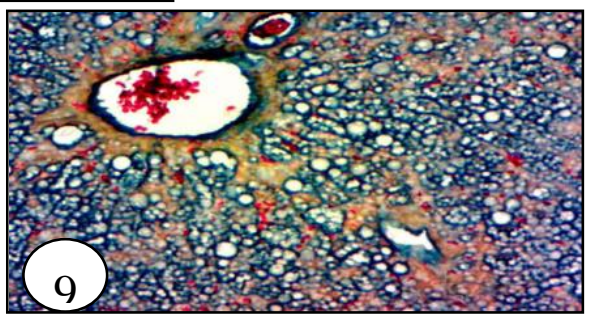

Fig.(1\&2)Showing photomicrographs of liver tissue of a control rat. 1- Showing the central vein ( cv ), sinusoidal spaces ( $\mathrm{s}$ ), kupffer cells ( $\mathrm{k}$ ) and hepatocytes ( $\mathrm{H}$ ).

2-The portal area contains a branch of the hepatic portal vein (hpv), bile duct ( bd ) and a branch of the hepatic artery ( ha ). (HX \& E X100) . Fig.(3): Showing photomicrographs of liver tissue of rats treated with fats (hyperlipidemia)for 3 weeks only.Numerous fatty cells, lymphocytic infiltration around the distorted central vein( $\boldsymbol{\nearrow})$, lots of vacuolated hepatocytes $\left({ }^{\wedge}\right)$ many pyknotic nuclei ( p) (HX \& E X100).

Fig. (4):Showing photomicrographs of liver tissue of rats treated with fats for 3 weeks and left 3 weeks for recovery.Lymphocytic infiltration around the central vein $(\boldsymbol{\pi})$, increased kuffer cells $(\mathrm{k})$, fatty degeneration $(\mathrm{F})$ with many vacuolated hepatocytes and haemolysed RBCs inside the central vein (HX \& E X100). Fig.(5): Showing remarkable recovery in the liver tissue of a rat treated with fats for 3 weeks then 3 weeks with triphala. (HX $\& \mathbf{E}$ X100). Fig.(6): Showing noticeable recovery in the liver tissue of a rat treated with fats and triphala for 6 weeks simultaneously. (HX \& E X100).

Figs.(7 \&8): Showing normal distribution of collagen fibers in the liver tissue of a control rat. Notice thin collagen bundles supporting the central vein (cv), hepatocytes ( H ), sinusoidal spaces ( S ), hpv and walls of bile duct.

(Mallory's trichrome stain X 100). Fig.(9):Showing increased collagen fibers in the liver tissue of a rat treated with fats (hyperlipidemia) for 3 weeks only. Collagen fibers increased around the hepatocytes, branches of the hepatic portal vein, hepatic artery, while, collagen fibers decreased in the wall of the central vein (Mallory's trichrome stain X 100). 

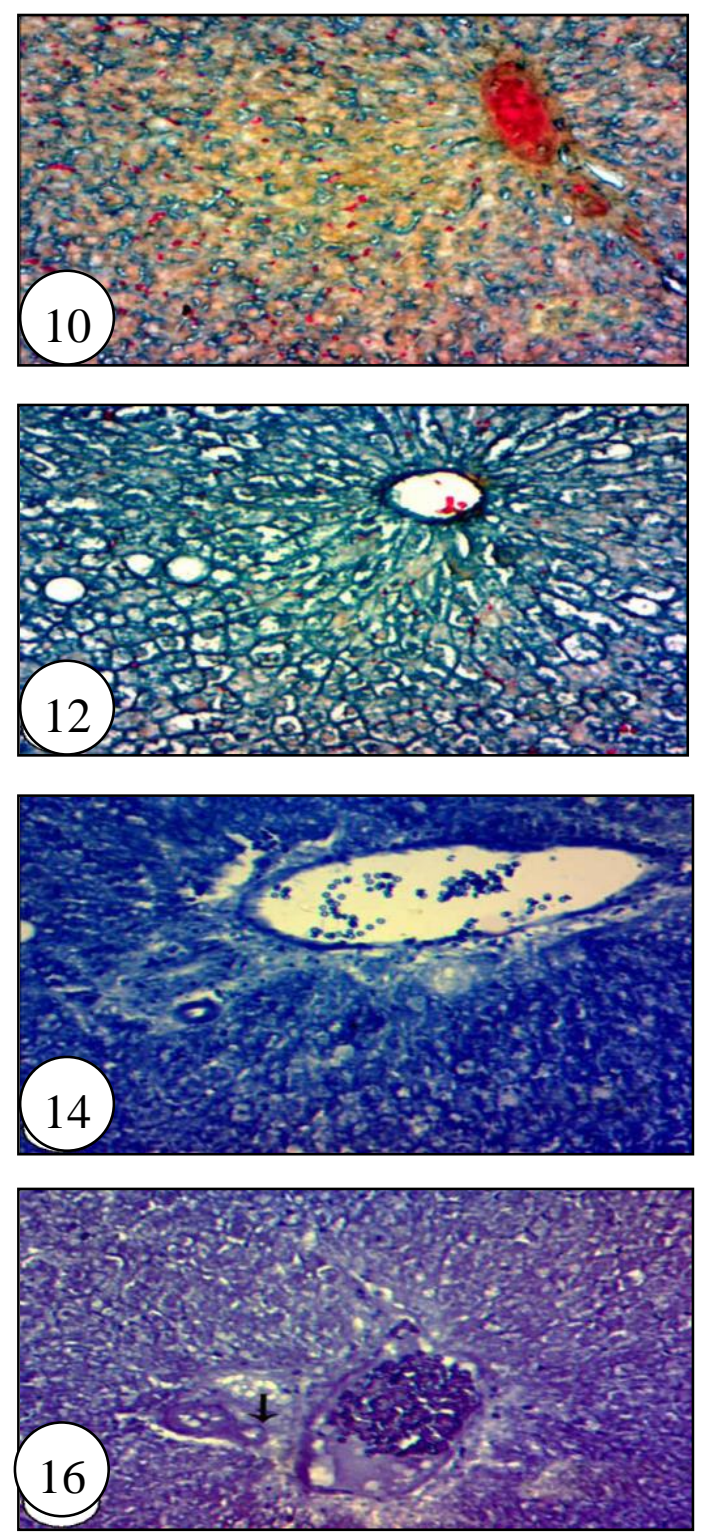
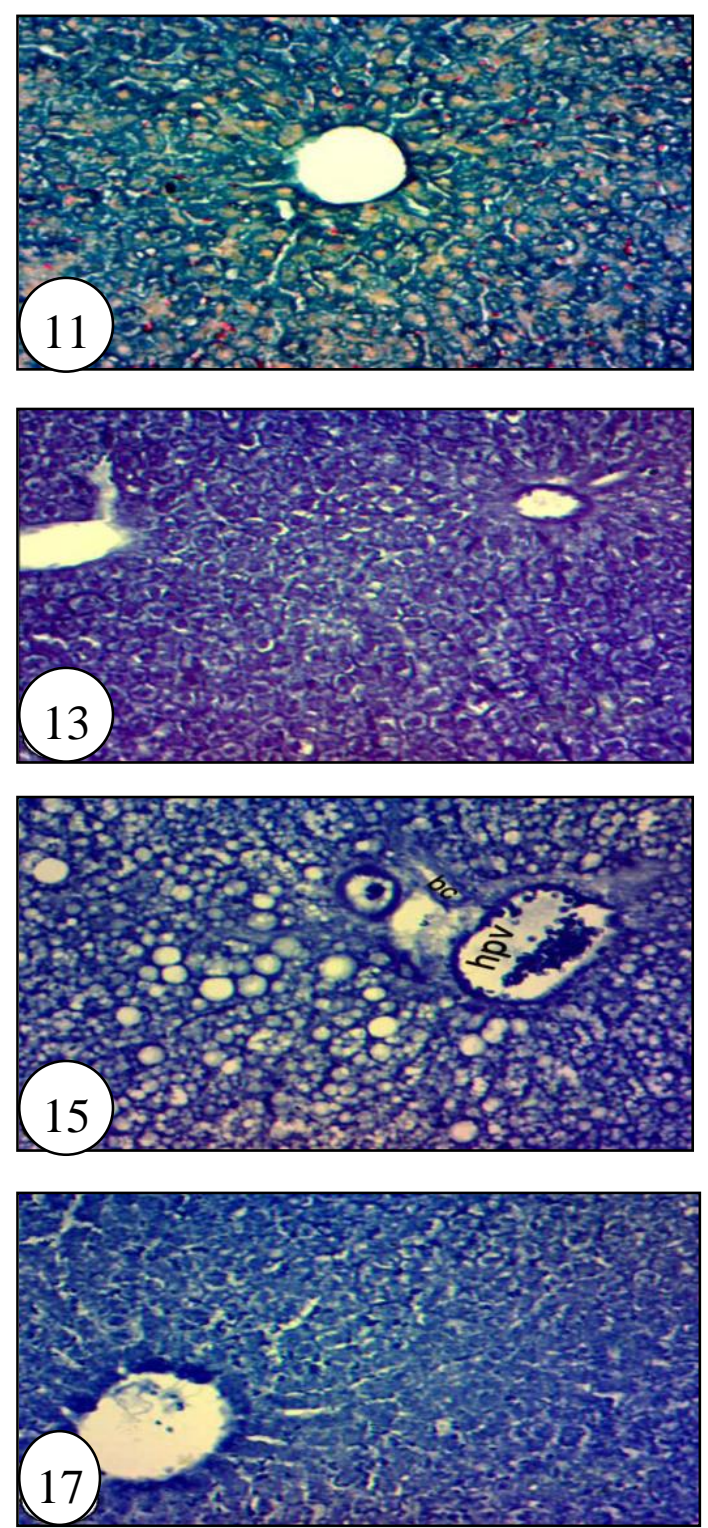

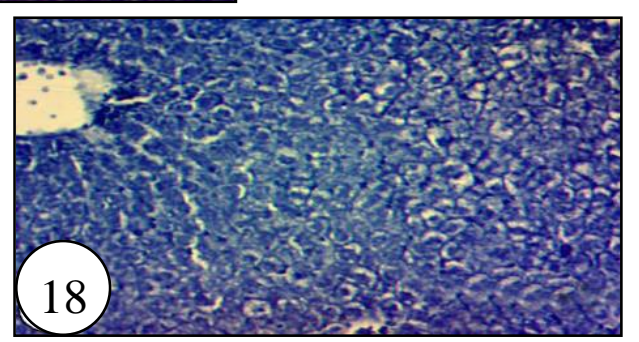

Fig.(10): Showing Increased collagen fibers around most hepatocytes and sinusoidal spaces in the liver tissue of a rat treated with fats for 3 weeks and left 3 weeks for recovery (Mallory's trichrome stain X 100). Fig.(11):Highly increased collagen fibers in the central vein, hepatocytes and sinusoidal spaces in the liver tissue of a rat treated with fats for 3 weeks then 3 weeks with triphala (Mallory's trichromestain X100). Fig.(12): Showing increased collagen bundles in the central area of liver tissue of a rat treated with fats and triphala for 6 weeks simultaneously (Mallory's trichrome stain x100). Figs.(13\&14): Showing normal distribution of total proteins in the central and portal areas inthe liver tissue of a control rat(Mercuric bromophenol blue $\mathbf{X}$ 100). Fig.(15): Showing highly reduced total proteins in the walls of the hepatic portal vein (hpv), and hepatocytes in the liver tissue of a rat treated with fats ( hyperlipidemia) for 3 weeks only (Mercuric bromophenol blueX 100). Fig.(16): Showing a mild decrease in total proteins in the walls of the central vein of liver tissue of a rat treated with fats for 3 weeks and left 3 weeks for recovery (Mercuric bromophenol blue X 100). Fig.(17): Showing nearly normal distribution of total proteins in the central area of liver tissue of a rat treated with fats for 3 weeks then 3 weeks with triphala (Mercuric bromophenol blue X 100). Fig.(18): Showing total proteins distribution in the liver tissue of a rat treated with fats and triphala for 6 weeks simultaneously. Some hepatocytes were faintly stained, while, others were nearly normal (Mercuric bromophenol blue X100). 


\section{Discussion}

Hyperlipidemia : is an elevation of lipids in the blood stream and these lipids include: fats, fatty acids, cholesterol, cholesterol esters, phospholipids, and triglycerides. Coronary heart disease (CHD) is caused by the narrowing of the artery that supplies nutrients and oxygen to the heart. The main reason for this narrowing is atherosclerosis. There is a relationship between the elevated plasma lipids and the development of atherosclerotic plaques (Jain et al., 2007).

\section{Body weight:}

Consumption of high fat diet led to obesity and overweight probably because it facilitated the development of a positive energy balance leading to an increase in visceral fat deposition, this lead to abdominal obesity in particular (Amin and Nagy, 2009). In the present investigation, triphala reduced the body weight gain. This may be due to the active components, hydroxyl-anthracene

glucosides compounds, in triphala which improve gastrointestinal motility and influence colonic motility thereby reducing fluid absorption and facilitating weight loss (Amin and Nagy, 2009).

\section{Glucose level:}

Obesity is associated with decreased ability of the body to control blood glucose with normal levels of insulin (Kuczmarski et al., 1994; Bloomgarden, 2004).Reduction in glucose level by triphala is probably mediated through enhanced secretion of insulin from the beta-cells of the pancreatic islets or through an extra pancreatic mechanism. Moreover, triphala may reduce inflammatory cytokine release during diabetes, which may be one of the causative agents for the insulin resistance (Rao and Nammi, 2006).

\section{Liver and heart functions:}

Injury to liver tissues due to hyperlipidemia alters their transport function and membrane permeability, leading to leakage of enzymes from the cells. Therefore, the marked release of
ASAT, ALAT and GGT into the circulation indicates severe damage to hepatic tissue membranes (Ahn et al., 2007). Gallic acid (GA) present in triphala is reported to possess hepatoprotective and antioxidant activities. The quantification of GA can be used as an index in routine quality control of triphala and its different constituents (Kumagai et al., 2003).

In the present study triphala reduced the level of liver enzymes as compared with the hyperlipidemic groups.These results are in agreement with those obtained by Jadon et al. (2007), who showed that gallic acid, at $50 \mathrm{mg} / \mathrm{kg}$ body weight, could decrease plasma ASAT, ALAT and GGT activities elevated by acute hepatic damage.

Suchalatha and Shyamala (2004) reported that triphala extract treatment ameliorates the effect of lipid peroxide formation that is related to the activities of diagnostic myocardial marker enzymes.

Improvement of cardiac muscle function and subsequent improved pumping activity of the heart seems to be the primary benefit of triphala (Singh et al., 1982).

\section{Protein profile:}

Increase in serum total protein and albumin in hyperlipidemic rats was observed and was explained by increased amino acids synthesis and greatly increased concentration of a variety of essential amino acids( Brosnan et al., 1984), increase in protein synthesis which in turn may be due to increase in the amount and availability of mRNA, increase in translation factor and increase in ribosomal protein synthesis as a result of hyperlipidemia (Peavy et al., 1985).

Treating with triphala decreased total proteins and albumin, due to reducing amino acids synthesis and this led to reduction in ribosomal protein synthesis at the end of the cascade of events and returned to normal values as a result of antioxidant, antimutagenic and free radical scavenging activity of this plant (Wool $\boldsymbol{e} t$ al., 1986). 


\section{Liver total lipids:}

Hyperlipidemia is a genetic disorder of lipid metabolism associated with insulin resistance and abnormalities in fatty acid metabolism. It is characterized by an increase cardiovascular risk (Cavallo $\boldsymbol{e t}$ al., 2005; Martijn et al., 2008).In the current investigation, triphala significantly turned back liver total lipids to the normal values.This may be due to inhibition of hepatic cholesterol biosynthesis that led to increased fecal bile acid excretion, and stimulation of receptor-mediated catabolism of LDL-cholesterol caused triphala's lipid-lowering effects (Khanna et al., 1996). Our observations were in agreement with Kirby et al.(2004) who stated that significant decrease in the liver total lipids may be due to reduction in the absorption of cholesterol, and they found that oral administration of triphala reported to increase gastric emptying and this might be the reason for decrease in the cholesterol absorption. Triphala has antioxidant and hypolipidaemic activity and also has free radical scavenger activity. It also protect myocardial necrosis and reduces cholesterol-induced atherosclerosis (Ram et al., 2003).

\section{The histopathological study:}

Hyperlipidemia is known to enhance the risk of fatty liver disease (Festi et al., 2004) and carcinogenesis which is associated with hydroxyl radical formation (Tseng et al., 1996). Antolin et al. (2009) noticed a relation between obesity and different degrees of fibrosis and chronic liver diseases and they added that liver transplant patients show increased rates of obesity.Fatty liver is associated with overweight, hyperlipidemia, hyperglycemia, hyperuricemia and alcoholism in Taiwanese (Changchien $\boldsymbol{e t}$ al., 2003).

Rats treated with fats for 3 or 6 weeks showed many pathological changes in the liver tissue. These changes were more pronounced in liver tissue of group H6. These changes include: ruptured endothelial lining of the blood vessels, enlarged nuclei of the endothelial lining, increased lymphocytic infiltration in the portal area, haemolysed RBCs inside the blood vessels with degenerated and vacuolated hepatocytes and fatty cells. The hepatic portal areas lost their normal architecture and contained highly distorted blood vessels and bile canaliculi.

In the present study rats of group $R$ showed no detectable signs of improvement in the hepatic tissue. Well developed hepatocytes were detected in the liver tissue of rats of group $\mathrm{H} 3 T$, but increased lymphocytic infiltration was detected in the portal area with moderate RBCs haemolysis inside the hpv. Detectable recovery was observed in the liver tissue of rats of group H6T , but some hepatocytes were still vacuolated with lymphocytic infiltration in the portal areas. Improvement in blood vessels architecture noted in liver of rats treated with fats and triphala in the present study was also observed by Jain et al. (2009) who noticed the cardio protective effect of this plant.

Results of the present study showed increased stain affinity of collagen fibers in liver of rats of groups $\mathrm{H} 3, \mathrm{H} 6$ and $\mathrm{R}$, especially around the hepatocytes, walls of hepatic portal veins and the arterial walls with decreased stain affinity in the wall of the central vein.

Enzan et al. (1995) attributed a similar finding to the activation of myofibroblastlike cells present normally within the hepatic and renal parenchyma. George $\boldsymbol{e t}$ al. (2001) suggested that decreased synthesis of collagenolytic enzymes by the impaired hepatocytes might contribute to further accumulation of collagen. Liver of rats of group $\mathrm{H} 3 T$ \& $\mathrm{H} 6 T$ showed increased collagen fibers in walls of blood vessels, hepatocytes and sinusoidal spaces. Hassan et al. (1988) reported that increased collagen fibers may lead to increased defensive reaction against toxic materials.

\section{The histochemical study:}

Highly reduced total proteins was detected in liver tissue of groups H3 \& H6, but nearly normal protein content was realized in hepatocytes of liver tissue of group R, but a mild decrease was noted in walls of the blood vessels and bile canaliculi. Some what normal protein content was observed in liver tissue of groups H3T and H6T. Some vacuolated hepatocytes and fatty 
cells were negatively stained with deeply stained RBCs inside the congested blood vessels. According to EI Banhawy et al. (1986) decreased protein content in the liver tissue may be due to increased action of lytic enzymes. In 2007, Eid and Al Dossary stated that decreased protein content in liver tissue may be due to the drastic effect on rough endoplasmic reticulum (RER), mitochondria and Golgi apparatus and increased lysosomes in hepatocytes.

\section{Conclusion \& recommendations:}

Results of the present study showed that triphala has hypolipidemic action specially when used with fat free diet for treating hyperlipidemia.So,we recommended to use it for treatement of hyperlipidemic patients.

\section{References:}

Ahn T H, Yang Y S, Lee J C and Moon C J (2007): Ameliorative effects of pycnogenol on carbon tetrachloride- induced hepatic oxidative damage in rats. Phytother. Res., 21: 1015-1019.

Amin K A and Nagy M A (2009): Effect of carnitine and herbal mixture extract on obesity induced by high fat diet in rats. Diabetic and Metabolic Syndrome J., 1: 1-17.

Antolin G S, Pajares F G and Vallecillo M A (2009): Fibroscan evaluation of liver fibrosis in liver transplantation. Transplant. Unit. Rio Hortega Unive. Valladolid, Spain, 41: 1044-1046.

Arora S, Kaur $K$ and Kaur S (2003): Indian medicinal plants as a reservoir of protective phytochemicals. Teratog. Carcinog. Mutagen, 1: 295-300.

Bergmeyer H U (1978): Principles of enzymatic analysis. Verlag. Chemic., 21 (5): 823-887.

Bloomgarden $\quad$ Z T (2004): The $1^{\text {st }}$ world congress on the insulin resistance syndrome. Diabetes Care, 27: 602-609.

Breuer J (1996): Report on the symposium "Drug effects in clinical chemistry methods". Eur. J. Clin. Chem. Clin. Biochem., 34:385386.

Brosnan J T, Man K C, Hall H E, Clobourne S A and Brosnan M E (1984): Interorganmetabolism of amino acids in hyperlipidemic rat. Am. J. Physiol., 244:151158.

Cavallo M, Montali A, Monetini $L$ and Valente L (2005): Tumor necrosis factor alpha $(\mathrm{TNF} \alpha)$ and its soluble receptor p75 in familial combined hyperlipidemia. Nutrition Metabolism and Cardio. Disea., 15: 262-269. Changchien C, Wang J, Tsai T and Hung C (2003): Correlation between fatty liver and lipidemia in Taiwanese. J.Med. Ultras., 11(2):60-65.

Chattopadhyay R R and Bhattacharyya S K (2007): Terminalia chebula: an update. Pharmaco. Revi., 1: 151-156.

Choudhary M I, Naheed S, Jalil S, Alam J $M$ and Rahman A (2005): Effects of ethanolic extract of Iris germenica on lipid profile of rats fed on a high-fat diet. J. Ethnopharmacol., 98: 217-220.

Doumas B T, Watson W A and Biggs H G (1971): Albumin standard and the measurement of serum albumin with bromocresol green. Clin. Chem. Acta., 31:8796.

Drury $R$ and Wallington E (1980): Carleton's Histological Technique, $4^{\text {th }}$ Ed. Oxford. Univ. Press, New York, Toronto.

Eid F and Al-Dossary A (2007): Ultrastructural, histological and histochemical studies on the effect of electromagnetic field on the liver of pregnant rats and their fetuses. The Egypt. J. of Hospital Medicine, 28: 273294.

El Banhawy M, Al-Zahaby $\mathbf{E}$ and Shalaby A (1986): Effect of Cyolane intoxification of the protein contents in epithelial cells of Clarias lazera. Egypt. J. Histo., 9(1): 69-76.

Enzan H, Himeno H, Iwamura S, Saibara T, Onishi S, Yamamoto Y, Miyazaki E and Hara H (1995): Sequential changes in human cells and their relation to post necrosis liver fibrosis in massive and submassive hepatic necrosis. Virchows Archi., 426: 95-101.

Feng $\mathrm{L}$, Yu C, Ying $\mathrm{K}$, Hua $\mathbf{J}$ and Dai $\mathrm{X}$ (2011): Hypolipidemic and antioxidant effects of total flavonoids of Perilla frutescens leaves in hyperlipidemic rats induced by high-fat diet. Food Resear. Int., 44(1): 404-409.

Festi D, Colecchia A, Sacco T, Bondi M, Roda E and Marchesini G (2004): Hepatic steatosis in obese patients: clinical aspects prognostic significance. Obesity Reviews, 5: $27-42$

George I, Ramesh k, Stem $\mathbf{R}$ and Chandrakasan G (2001): Dimethyl nitrosamine-induced liver injury in rats: the early deposition of collagen. Toxicology, 156: 129-138.

Hassan H, Ghaly E, El-Nashar A and Manggoud H (1988): Histochemical study on some organs of rats fed rape seed and 
cotton seed oils. Egypt. J. Histol., 11(2): $247-$ 252.

Jadon A, Bhadauria $M$ and Shukla $S$ (2007): Protective effect of Terminalia belerica and gallic acid against carbon tetrachloride induced damage in albino rats. J. Ethnopharmacol., 109 : 214-218.

Jagetia G, Baliga $M$, Malagi $K$ and Kamath M (2002): The evaluation of the radio protective effect of triphala (an Ayurvedic rejuvenating drug) in the mice exposed to gamma-radiation. Phytomedicine, 9 (2): $99-108$.

Jagetia G, Prathapan D and Leeny T (2004): Triphala, an ayurvedic rasayana drug, protects mice against radiation-induced lethality by free-radical scavenging. J. Altern. Comple. Med.,10(6):971 - 978.

Jain K S, Kathiravan M K, Somani R S and Shishoo C J (2007): The biology and chemistry of hyperlipidemia review. Bioorgan. Med. Chem., 15: 4674 - 4699.

Jain S, Yadav $P$ and Gill $V$ (2009): Terminalia arjuna a sacred medicinal plant: phytochemical and pharmacological profile. Phytochem. Rev., 8: 491-502.

Kaplan A (1984): Quantitative Determination of Total Lipids. Clin. Chem. The C.V.Mosby Co. St. Louis. Toronto. Priceton, 919-932.

Kaur S, Arora S, Kumar S and Nagpal A (2002): Antimutagenic activities of acetone and methanol fractions of Terminalia arjuna. Food Chem. Toxicol., 40 : 1475 - 1482.

Khanna A, Chander $\mathbf{R}$ and Kapoor $\mathbf{N}$ (1996): Terminalia arjuna: an ayurvedic cardiotonic regulates lipid metabolism in hyperlipidaemic rats. Phytotherapy Res., 10 : $663-665$.

Kirby J, Philip N and Howles Y (2004): Hypolipidemic effect of triphala in experimentally induced hypercholesteremic rats. Hui. J. Lipidol. Res., 45: 89-98.

Kolovou G D, Anagnostopoulou K K and Cokkinos D V (2005): Pathophysiology of dyslipidaemia in the metabolic syndrome. Postgrad Med. J., 81(956): 358-366.

Kuczmarski R J, Flegal K M, Campbell S $M$ and Johnson C L (1994): Increasing prevalence of overweight among U.S. adults. The national health and nutrition examination surveys. JAMA 272: 205-211.

Kumagai J, Kwaura T and Miyazaki $\mathbf{T}$ (2003): Test for antioxidant ability by scavenging long-lived mutagenic radicals in mammalian cells and by blood test with intentional radicals: an application of gallic acid. Rad. Phy. Chem., 66: 17-25.

Martijn C G, Jose G and Casper G S (2008): Plasma PAI-1 levels are independently related to fatty liver and hypertriglyceridemia in familial combined hyperlipidemia involvement of apolipoprotein E. Thrombosis Res., 122: 466-472.

Mazia D, Brewer $P$ and Alfert $M$ (1953): The cytochemical staining and measurement of protein with mercuric bromophenol blue. Biol. Bull., 104: $57-67$.

Palav Y K and D'mello P M (2006): Standardization of selected Indian medicinal herbal raw materials containing polyphenols as major phytoconstituents. Indian J. of Pharmace. Scien., 68:506-509.

Pearse A (1977): Histochemistry, Theoretical, and Applied. $3^{\text {th }}$ ed., vol. 1. Churchill Livingstone, London.

Peavy D E, Taylor J M and Jefferson L S (1985): Time course of changes in albumin synthesis and mRNA in hyperlipidemic rats. Am. J. Physiol., 248:656-663.

Ram M, Neetu D, Deepti P, Vandana M and Kumar D (2003): Cytoprotective activity of Amla (Emblica officinalis) against chromium induced oxidative injury in murine macrophages. Phytother. Res., 17(4): 430-433.

Rao N K and Nammi S (2006): Antidiabetic and renoprotective effects of the chloroform extract of Terminalia chebula Retz seeds in streptozotocin-induced diabetic rats. BMC. Complementary Alterna. Medici., 7(6): 17-20.

Sabu M C and Kuttan R J (2002): Antidiabetic activity of medicinal plants and its relationship with their antioxidant property. J. Ethnopharmacol., $81: 155-160$.

Sandhya T, Tomas $M$ and Aleany B (2006): Potential of traditional ayurvedic formulation triphala as a novel anticancer drug. Cancer Letters, 231:206-214.

Singh N, Kapur $K$ and Singh $S$ (1982): Mechanism of cardiovascular action of triphala. Planta Med., 45: 102-104.

Snedecor G W and Cochran W G (1980): Statistical Method. State University Press, Lowa, 59-60 . USA.

Suchalatha S and Shyamala D (2004): Protective effect of Terminalia chebula against experimental myocardial injury induced by isoproterenol. Indian J. Exp. Biol., 42: 174178.

Szasz G and Persijn J P (1974): Determination of $\mathrm{g}$-glutamyl transferase ( $\mathrm{g}$ glutamyl) - peptide: amino acid gglutamyltransferase. Clin. Chem. Biochem., 12: $228-238$.

Thomas L S (2000): Medicinal Plants, Culture, Utilization and Pharmacology. Technomic Publishing Co. Inc., Lancaster, Basel. Pp.: $20-55$. 
Fatma Eid... et al

Tietz N W (1994): Determination of Total Proteins. Fundamentals of Clinic. Chemis. Saunders Co., London, Philadelphia, 692-772.

Trinder P (1984): Determination of blood glucose using 4- aminophenazone. J.Clin. Path., 22: 246- 252.

Tseng T H, Hsu J D, Chu C Y and Wang C J (1996): Promotion of colon carcinogenesis through increasing lipid peroxidation induced in rats by a high cholesterol diet. Cancer Lett., 100: 81-87.
Wool I G, Strire - Walt W S, Karrhara $\mathbf{K}$, Low $\mathbf{R} \mathbf{B}$, Bailey $\mathbf{P}$ and Oyer $\mathbf{P}$ (1986): Mode of action of insulin in regulation of protein biosynthesis in muscle. Recent Progress in Hormone Research. New York Academic Press, Pp.: 124-139.

Young D S (1990): Effect of Drugs on Clinical Laboratory Tests. AACC. Pres. Washington, D.C., 32:639-655. 


\title{
تخفيض نسبة الدهون بإستخدام نبات الهليلج فى إناث الجرذان
}

\author{
فاطمة أحمد عيد، إيمان جمال الدين عزت هلال وأميرة محمد صلاح الدين أحمد الوحش الوان الوان

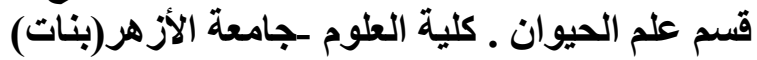

إستهدفت هذه الدراسه إيضاح الدور الوقائى لنبات الهليلج ضد الأخطار الناتجه عن زيادة الدهون على الدي

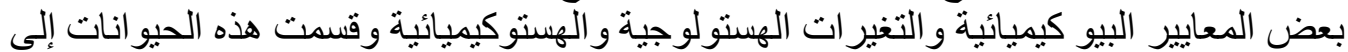

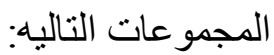

1-المجمو عة الأولى:- استخدمت كمجمو عه ضابطه.

2-المجموعة الثانية:- مجمو عة الجرذان المصابة بالدهون(25\% دهونه 2\% كو لستيرول) لمدة ثلاثة أسابيع فقط ثم تم ذبحها.

3-المجمو عة الثالثة:- مجمو عة الجرذان المصابة بزيادة الدهون لمدةثلاثة أسابيع ثم تركت ثناثنة

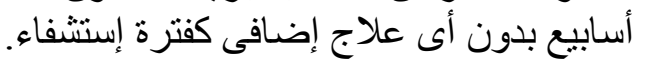

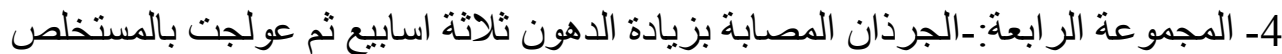

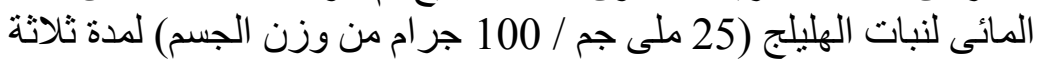

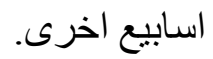

5-المجموعة الخامسة: المجموعة المصابة بالدهون لمدة ستة أسابيع (25\% دهون\& 2\%

$$
\text { كولستيرول). }
$$

6-المجمو عة السادسة:- مجمو عة الجرذان المصابة بزيادة الدهون وفى نفس الوقت تم معالجتها

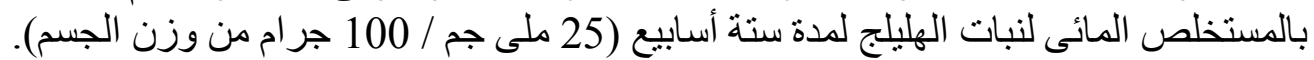

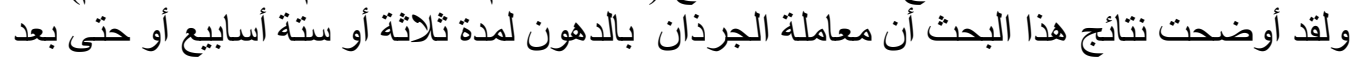

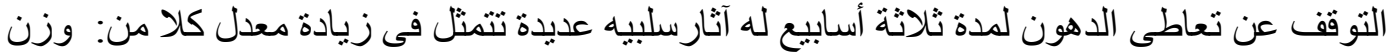

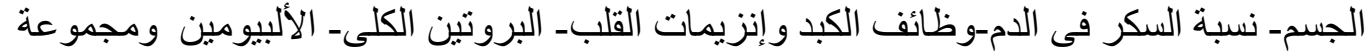

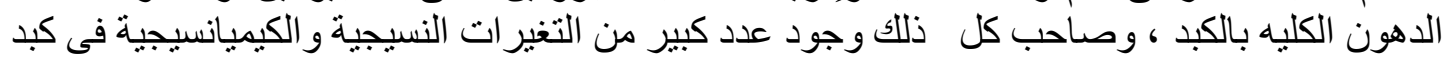

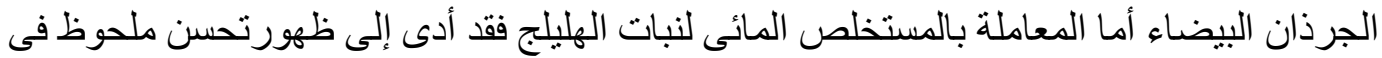

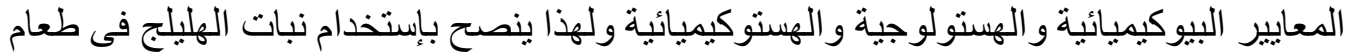

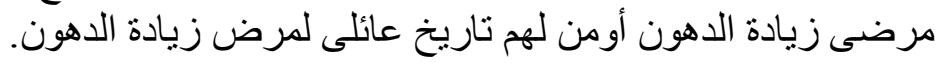

